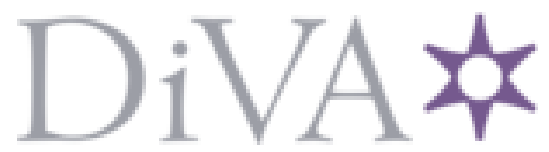

http://www.diva-portal.org

\title{
Postprint
}

This is the accepted version of a paper published in Gerontology \& Geriatrics Education. This paper has been peer-reviewed but does not include the final publisher proof-corrections or journal pagination.

Citation for the original published paper (version of record):

McCall, M E., Börjesson, U. (2017)

Integration or specialization? Similarities and differences between Sweden and the United States in gerontology education and training.

Gerontology \& Geriatrics Education, 38(1): 47-60

https://doi.org/10.1080/02701960.2016.1232592

Access to the published version may require subscription.

N.B. When citing this work, cite the original published paper.

Permanent link to this version:

http://urn.kb.se/resolve?urn=urn:nbn:se:hj:diva-34065 
Integration or Specialization in Gerontology: Sweden and the United States?

\section{Integration or Specialization? Similarities and Differences between Sweden and the United States in Gerontology Education and Training}

This article examines the similarities and differences in the education and training of those who work with older people in Sweden and the United States. Both countries are aging, though Sweden more quickly than the U.S., and Sweden began greying before the U.S. (Centers for Disease Control (CDC), 2003; Schellevis, 2013). In some ways, then, Sweden has had more time to assess its needs for gerontologically trained staff and to implement education and training programs in its country. Interestingly, though Sweden has virtually no post-baccalaureate programs specifically in gerontology, with most training coming either on the job, or through other disciplinary training (e.g., nursing or social work) with a focus on elderly. Most professionals who work with older persons come from other fields such as nursing, social work, medicine, etc. and most would not call themselves gerontologists, though this is beginning to change, as we discuss below. On the other hand, the U.S. has historically had a large range of post-secondary options for acquiring training and education in gerontology, both solely focused on gerontology, and within other disciplines (e.g., nursing, psychology). These programs in the U.S. range from a bachelor's level major or minor, master’s degree or $\mathrm{PhD}$ in gerontology, as well as a myriad of face-to-face or on-line certificate programs. Fagerberg \& Gilje (2007), in their study comparing Swedish and US nursing curricula, call for a deeper consideration of the preparation for those working with the elderly, as do Wrede, Henriksson, Host, Johansson \& Dybbroe (2008). This paper responds to that call. Part of the differences they and we have seen, reflect underlying cultural values, both around aging, and around educational models, which we will explore here. The implications for the two nations of these educational and training systems are critical to assess as we move into the century of aging around the world, and to consider what we might learn from each other as we face similar challenges of aging societies. The educational debate on gerontological training remains focused on whether knowledge should be integrated across all subjects related to health and social care, or should be utilized through 
Integration or Specialization in Gerontology: Sweden and the United States?

more courses that are specialized. The aim of this article is to examine the situation in Sweden and the US and respond to this question.

To this end, we first outline the aging trends in both countries and then discuss a broader view of attitudes towards aging and older persons in both countries. These attitudes have implications for the conception of how and what support elders need. Then, we outline the structure, levels, and types of gerontology education and training for those who provide care to older persons in a variety of fields. Given the different cultural, value, and educational contexts of the two countries, we will discuss whether we see a convergence of the types of efforts to train those who support older persons, or a continued divergence of strategies, and if so, how we might be able to understand them (Davey, Malmberg \& Sunstrom, 2013; Parker, 2000). In conclusion, we offer some recommendations for what the two countries can learn from one another in these efforts, and how we might reconceive gerontological education and training in the $21^{\text {st }}$ century.

\section{Demographic changes in the United States and Sweden}

Life expectancies at all ages have improved for many years now across the world, including the U.S. and Sweden (see Table 1). This means that both the U.S. and Sweden will continue to "grow" the number of people over the ages of 65 and one of the fastest growing groups will be those over 85, those with the greatest need for support.

While the aging of the baby boomers in both countries will increase the proportion of the older population, projected immigration into the working ages will tend to slow the overall rate of aging in the U.S. In Sweden, where there is a very recent influx of immigrants and refugees due to wars in other countries, it is unknown how much of an impact that will have on their overall population structure. Statistics Sweden (2014) reports that in 2012, 20.1\% of all residents had a "foreign background,” though there are varying future projections for the number of older people who will be foreign born, ranging from around 1.5 million people 65-79 years, to another .5 million over 80 years. In the U.S., although the older 
Integration or Specialization in Gerontology: Sweden and the United States?

population is not expected to become "majority-minority" in the next four decades, it is projected to be 39.1 percent minority in 2050, up from 20.7 percent in 2012; so both countries will need more training in providing culturally appropriate services and research (Ball, Perkins, Hollingsworth, Whittington, \& King (2009).

\begin{tabular}{|l|l|l|l|l|l|l|l|}
\hline YEAR & LExp@birth & LExp@65 & LExp@85 & & YEAR & \%65+minority & \%86+minority \\
\hline & Sweden/U.S. & Sweden/U.S. & Sweden/U.S. & & & U.S.* & U.S.* \\
\hline 1972 & $74.7 / 71.2$ & $15.7 / 15.2$ & $4.9 / 5.5$ & & 2012 & 20.7 & 16.3 \\
\hline 2010 & $81.5 / 78.7$ & $19.8 / 19.1$ & $6.2 / 6.5$ & & 2050 & 39.1 & 29.7 \\
\hline
\end{tabular}

*Sweden does not track the category of "foreign-born” by these age groups.

Table 1. Life expectancies for United States and Sweden.

The United States is aging, but, relative to other countries, it remains younger, mostly due to immigration of younger person (An Aging Nation: The Older Population in the United States, 2014). Yet, in Sweden, by 2030, the total net increase in the working age group will come from the foreign-born populace (Commission on the Future of Sweden, 2013), and 25\% of the workforce will be from other countries ( $80 \%$ from outside the EU). Thus, both countries have the potential of a workforce to address many social challenges, including elder care, and immigrant care of seniors is already happening in many Western countries (Spencer, Martin, Bourgeault \& O’Shea (2010). However, this calls for appropriate training of newcomers to fulfill these roles. If the workforces, though, are more diverse than those receiving care, at least, initially, then this will also need to be accounted for when training people to provide support to older persons.

Implications of demographic changes for gerontological services. All these changes have implications for elder care and support services, as well as the education/training needed to respond. 
Integration or Specialization in Gerontology: Sweden and the United States?

Longer lives, for example, will increase the prevalence of comorbidity in both countries (Schellevis, 2013), increasing the need for physical care. The changing sex ratios in both countries in later life also will pose challenges. While women will most likely continue to outlive men, life expectancy for is projected to increase more than for women. This could result in a smaller share of women living alone at the oldest ages in the future, at least for the youngest old (i.e., ages 65 to 84) (National Institute on Aging, National Institutes of Health \& U.S. Department of Health and Human Services, 2007). In Sweden, we have seen the phenomenon of "living apart together" among older persons, which will challenge these couples and partners, living sometimes hours apart, when care needs arise (Borell \& Ghazanfareeon Karlsson, 2003). In addition, because men and women can expect to survive to older ages, spouses may be able to care for one another longer, which will demand more education of and support for caregivers. There will also be increased demand for assisted-living arrangements or institutional care for couples; it is already happening in both countries (Kemp, 2008; Parker, 2000). As noted above, we will also see greater diversity by national origin, ethnicity and social class, as well, calling for different types of training than simply medical knowledge about biological aging processes (Ball, et al., 2009).

No matter the prognosis for aging trends, social and health services in both countries are major employers and the issues of education and training are important to examine. Next, we look at the rhetoric and attitudes about aging, which forms the foundation for policies and systems of education and training in both countries. Then we turn to the comparison of actual education and training for staff, and then discuss what we believe we can learn from each other in order to provide quality care and support for older persons.

\section{Tone and rhetoric about aging in Sweden, Europe, and the United States}

Aging is often seen as a coming disaster in the US and Sweden; it has been characterized as a “tsunami” or "silver surge” (Barry, 2008). On the other hand, we can see the relatively quick growth of the "positive aging" and "successful aging” movements in the U.S. As much as successful aging has been touted as a reachable goal, McLaughlin, Connell, Heeringa, Li, \& Roberts (2010), utilizing data from the 
Integration or Specialization in Gerontology: Sweden and the United States?

Health and Retirement survey, found that only $11.9 \%$ of people in the U.S. met the criteria for "successful aging." Critics have called these criteria judgmental and putting the "blame” on individuals if they are not positive or successful (see review by Martinson \& Berridge, 2014). However, they have become attractive catch phrases that are seen in the public press as well as foundations which want to fund research on the factors that contribute to them, (e.g., The Rochester Area Community Foundation: http://www.racf.org/Grants/Grant-Opportunities and the Gary and Mary West Foundation: http://www.westhealth.org/).

In Sweden, along with many European countries, the term more often heard is "active ageing.” (For example, in 2015, there was a European Summit on Innovations for Active and Healthy Aging (http://ec.europa.eu/research/innovation-union/index en.cfm?section=active-healthy-ageing\&pg=2015$\underline{\text { summit})) . ~ A n ~ e m p h a s i s ~ o n ~ a c t i v e ~ a g e i n g ~ a n d ~ r e s p o n s e s ~ t o ~ t h a t ~ i s ~ p r e s e n t e d ~ a s ~ a ~ s o l u t i o n ~ t o ~ n e e d s ~ i n ~ a g e i n g ~}$ societies. This ideal scenario highlights the interplay between the individual and society, leading to an improved quality of life for individuals and a lower economic burden of care for society (Walker, 2002).

This rhetoric of active, productive, or successful aging is a double-edge sword - it provides a positive image that counteracts historical negative stereotypes about older persons; however, it can also lead to an overemphasis on the responsibility of the individual in their own care, leading to perhaps a more negative attitude towards those who do need care. A study of attitudes in Sweden towards aging showed that it is often perceived of as frightening and something to be avoided (Wilinska, 2012). As a consequence, working in elder care in Sweden, as in the U.S., is considered low status work (Spender, et al., 2010; Wrede, et al., 2008) and is associated with stressful working conditions (Trydegård \& Thorslund, 2010). Recent discussions in Sweden have drawn attention to the lack of quality in elder care, and neglect and abuse of seniors have been reported in both countries (Lachs \& Pillemer, 2015; SOU, 2008). Wrede, et al. (2008), in a study of elder care in the Nordic countries, identified three signs of a crisis in elder care: 1) difficulty in recruiting personnel, 2) lack of educational models and a knowledge base, and 3) lack of valuation of the care worker (ibid p31). Since these concerns are also common in the 
Integration or Specialization in Gerontology: Sweden and the United States?

U.S. (Spencer, et al, 2010), both countries need to consider they can train a caring workforce in which residents can have confidence.

In a Swedish study, Engström and Fagerberg (2011) found that Registered Nurses (RNs) reported both higher positive scores towards older people, as well as lower negative scores, compared to nurses without an academic degree and Nursing Assistants. In addition, they found that progression in one's health care education contributes to reducing unfavorable attitudes toward older people. Studies among U.S. nursing students reported similar results (Yee, Shin \& Greiner, 2015). Kydd, Touhy, Newman, Fagerberg \& Engström (2104), in a study comparing attitudes towards caring for older persons in Scotland, Sweden, and the U.S., found Swedish carers to have attitudes that are more negative. Respondents reported this was due to working conditions, poor career prospects, and perceived lack of professional regard. Studies such as this suggest that social attitudes towards a specific specialty area within health care, from both consumers and other professionals, are important as they influence future career choices. Health care professionals need to have the right skills to manage a more demanding role in the future in order to offer effective services for older people. Therefore, a challenge for the future is to alter negative attitudes towards older people and the people who work with them, and to do that through the education and training is a key factor.

\section{Educational structures and systems in Sweden and the U.S.}

The increasing needs for care for elders in both countries calls the question about how the U.S. and Sweden are preparing staff who will work with these seniors. In this section, we outline the various options and paths for working with and caring for older people. First, we discuss some general cultural values, and structures, around the system of education. While both nations provide free public education through $12^{\text {th }}$ grade, the variation in quality is much greater in the U.S. than Sweden, largely associated with the economic class of those in the neighborhood of a given school. In Sweden, the government pays for post-secondary education, and it is largely self-study of a standard curriculum. In the U.S., individuals 
Integration or Specialization in Gerontology: Sweden and the United States?

pay privately for higher education (even if grants and scholarships are available), and there is more curricular variation, and is less organized around self-study.

Sweden's education system provides free access from primary through university education. Secondary education up until the age of 16 , or what would be considered $9^{\text {th }}$ grade in the U.S., is compulsory. Thereafter, individuals can choose to attend the gymnasium, or what in the U.S. are the $10^{\text {th }}$, $11^{\text {th }}$ and $12^{\text {th }}$ grades (high school). For some people, this is the end of their formal education and they may get jobs providing direct services to older persons, in the general field of Social Care (for which some training is provided at the gymnasium level). Many young people may then work for a few years before deciding to attend a university. It is generally a 3-3.5-year process to earn a bachelor's degree. The education is largely independently done, with some required lectures to attend, but students can also read the texts on their own and take the exams to pass. Universities offer a series of optional seminars, which often provide more in-depth and applied information from either Swedish faculty or foreign visiting faculty. The curriculum is consistent throughout the country at this level, so that the same degree, even from a different university, is consistent in what curriculum was covered. Post-baccalaureate options for education include a 1-year Magister degree, a 2-year Master's degree and a PhD in various fields. These post-baccalaureate degrees, especially the doctorate, though, are predominantly for those who want to pursue a research and/or academic career in aging, rather than working in the service sector, and so is not considered in-depth here.

In the United States, there is also a system of public, and generally obligatory, high school $\left(12^{\text {th }}\right.$ grade) education, though people can earn an equivalency diploma of a high school level education called the GED - General Education Diploma - through self-study. The U.S. also has many two-year "junior” colleges that may offer applied kinds of degrees, and then traditional 4-year colleges and universities, which, while one can expect some basic similarities across curricula, do not guarantee, for example, that every gerontology major has covered the same material. Licensed fields, such as nursing, social work, etc. are more likely to have common curricula. There are a myriad of master's and doctoral programs, as well. 
Integration or Specialization in Gerontology: Sweden and the United States?

Students in the U.S. have far more individual choice and multiple paths to work than in Sweden. In general, the U.S. is a system of specialization, while Sweden is largely a system of broader disciplinary or interdisciplinary studies. This then creates different challenges for the two systems in how to deal with needed changes in their systems.

\section{Education in gerontology and social care.}

There is growing awareness that the health care sector must compete with other sectors in order to attract well-educated caregivers who want to work for them. Engström and Fagerberg (2011) found that more than $30 \%$ of the caregivers employed in care for older people have no formal education. The formal educational training for nurse assistants (undersköterska) in Sweden may include upper secondary education, health care support training, and/or nurse assistant training. Assistant nurses have completed either the Upper Secondary Health Care Program, or a 32-week supplementary course (Ahnlund, 2008). Working as a manager in elder care typically requires a bachelor's degree in social work or social care. At the university level, while there are no specific programs in Gerontology, students in social work, nursing, occupational therapy, rehabilitation sciences, etc. can focus their work on older people if they so choose. People with a bachelor's or master's degree in social work, for example, can go directly into a manager position at various types of care homes or care organizations.

Sweden also has a 1-year “Magister” in gerontology (e.g., Jönköping University). This is similar to the certificate programs offered in the U.S. There is also the Nordic master's degree program in Gerontology - health science, social science, and behavioral science - for Sweden, Norway and Iceland a relatively new program that prepares students for research studies or a $\mathrm{PhD}$ program (https://ju.se/studera/program/program-pa-avancerad-niva/nordic-masters-degree-programme-in-

gerontology.html). People who earn a master's degree in social or health science, can go into a higher administrative position, or move on to earn a $\mathrm{PhD}$, again, though, not with a specific designation of gerontology as the field of study. At Jönköping University in addition, one can earn a PhD in Health and Caring Sciences, Welfare and Social Sciences, or Disability Research. The university allows someone to 
Integration or Specialization in Gerontology: Sweden and the United States?

focus on and study gerontology, and conduct their doctoral dissertation on aging, but the degree they earn will not be a Phd in Gerontology, specifically (see Table 2).

Swedish doctoral programs are organized around research programs, either those conducted by the faculty, or those that doctoral students bring with them, along with funding for that research. Sweden has several world-renown research institutes that focus on aging issues. These include: the National Institute for the Study of Aging and Late Life (NISAL - http://www.isv.liu.se) at Linkoping University in central Sweden; the Aging Research Center (ARC - http://ki-se-arc.se), coordinated by the Karolinska Institute and Stockholm University in Stockholm; the Center for Aging and Health (AGECAP http://www.agecap.gu.se) at the University of Gothenburg; and the new National Graduate School on Aging and Health (SWEAH - http://www.med.lu.se/sweah) at Lund University in southern Sweden. In addition, many other universities have similar research centers, or research projects, largely funded by the Swedish government at various levels (national to local) and/or the European Union. All these centers have collaborative relationships with other universities, with multiple disciplines involved, both offering courses and research opportunities.

\begin{tabular}{|l|l|l|l|}
\hline Degree & Title/ & Title/ & Title/ \\
& Department & Department & Department \\
\hline Magister & Social Work & Gerontology & Nursing \\
\hline Bachelor & Social Work & Gerontology & Nursing \\
\hline Master & Social Work & Gerontology & Nursing \\
\hline Doctoral & Social Work & Gerontology & Welfare and \\
& & & Social Sciences \\
\hline
\end{tabular}

Table 2. Examples of degrees related to gerontology at different levels in Sweden. 
Integration or Specialization in Gerontology: Sweden and the United States?

Programs in the United States. One of the similarities between Sweden and the United States is the option for focusing on older persons within many disciplines, including nursing, counseling, public health, psychology, oral health, physical and occupational therapies, etc. With a high school diploma or completion equivalency (GED), a person can enroll in a program to become a Certified Nursing Assistant (CNA), somewhat similar to an Assistant Nurse in Sweden. To become a CNA involves coursework (ranging from 6 weeks to 9 months), clinical internships, ranging from 16-75 hours, and an exam. CNAs may be employed in facilities or provide home health services. The U.S. also provides additional training for becoming a Licensed Vocational Nurse or Licensed Practical Nurse, who then can provide similar basic services such as vital signs, assistance with activities of daily living, etc., as well as administer medications. LVN/LPN training ranges from 12-24 months.

Unlike Sweden, the U.S. offers a wide range of more specialized degrees related to gerontology, as shown in the chart below (see Table 3). There are also numerous certificate programs in gerontology or related topics. Most certificate programs now are on-line and often self-paced. Completion times are between 9 months and 18 months, depending on credits needed and amount of time committed to completing the courses. They range from 4 courses at the University of Washington to 21 credits for a doctoral level certificate at the University of Massachusetts, Boston. There are also independent, nonacademic-based organizations that offer certificates in gerontology for continuing education for professionals such as nurses and psychologists. These few examples highlight both the range of, and degree of specialization in, areas related to gerontology available in the United States.

\begin{tabular}{|l|l|l|l|l|l|}
\hline Degree & Title/ & Title/ & Title/ & Title/ & Title/ \\
& Department & Department & Department & Department & Department \\
\hline Bachelor & Social Work & Psychology & Gerontology & & \\
\hline Master & Gerontological & Social Work - & Applied & Senior & (Mgmt)Huma \\
\hline
\end{tabular}


Integration or Specialization in Gerontology: Sweden and the United States?

\begin{tabular}{|c|c|c|c|c|c|}
\hline & Counseling & Gerontology & Gerontology & $\begin{array}{l}\text { Housing } \\
\text { Administratio } \\
\mathrm{n}\end{array}$ & $\begin{array}{l}\text { n Services - } \\
\text { Gerontology }\end{array}$ \\
\hline Doctoral & Gerontology & $\begin{array}{l}\text { Adult } \\
\text { Development } \\
\text { and Aging }\end{array}$ & Adult Learning & $\begin{array}{l}\text { Human } \\
\text { Development }\end{array}$ & \\
\hline Certificates & $\begin{array}{l}\text { Aging/Gerontolo } \\
\text { gy }\end{array}$ & $\begin{array}{l}\text { LTC } \\
\text { Administration }\end{array}$ & $\begin{array}{l}\text { Continuing } \\
\text { Education in } \\
\text { Nursing, } \\
\text { Psychology }\end{array}$ & & \\
\hline
\end{tabular}

Table 3. Examples of degrees and certificates related to gerontology at different levels in the United States.

\section{Efforts to improve education and staffing in gerontological care.}

In Sweden, the staff in elder are nurse assistants (Ahnlund, 2008). As noted above, the formal educational training for nurse assistants may include upper secondary education, health care support training, and/or nurse assistant training. However, not all care workers in elder care have a formal education. Törnquist (2006) and Axelsson \& Elmståhl (2002) have discussed the consequence of this lack of formal education, and described it as putting older individuals at risk. In 1992 in Sweden, a reform called ÄDEL transferred the responsibility of caring for older individuals from the county councils to the municipalities (Thorslund, 2002). As a result, this changed the conditions for elder care by an increased complexity of care support (Astvik \& Aronsson, 2000). The three-year national project 'Steps for Skills' (Kompetensstegen), was designed to support the development of quality through the development of staff competence in municipally-managed care for older individuals. Initiated in 2005, the project allocated just over 100,000,000 Euro and the focus was to create sustainable projects connected closely to the various 
Integration or Specialization in Gerontology: Sweden and the United States?

work places. Steps for Skills intended to improve the following areas of knowledge: case management, documentation, pharmaceuticals, oral health, prevention of injuries caused by falling, and dementia. The evaluation of Steps for Skills (SOU 2007:88, IMS 2009-126-179) indicated that changes in staff knowledge and skills were achieved in three of the designated six areas. The staff was educated in how to prevent falling accidents; trained in oral health, and new documentation routines were introduced; after completing their education, care managers were more likely to approve an application for an older individual to receive a needs assessment. However, this evaluation did not provide immediate consequences for older individuals. Moreover, the evaluation did not show a connection between teaching, improved knowledge, and changes in daily practice. More recently, The National Board of Health and Welfare in Sweden (2012) has again asked for increased competence in geriatrics and gerontology. They emphasized the need for specialist trained nurses and social workers in geriatrics and gerontology, for instance.

Similar to Sweden, the U.S. has made large investments in training of care providers. In 2003, the U.S. CDC's Advisory Committee to the Director identified five foci for CDC in regards to older adults: “1) provide high-quality health information and resources to public health professionals, consumers, health-care providers, and aging experts; 2) support health-care providers and health-care organizations in prevention efforts; 3) integrate public health prevention expertise with the aging services network; 4) identify and implement effective prevention efforts; and 5) monitor changes in the health of older adults” (p. 4). These roles require new ways to prepare professional to address the special needs of older adults and to situate programs in the communities in which older adults conduct various activities (work, leisure, etc.) (Goulding, Rogers, \& Smith, 2003).

The Employment and Training Administration (ETA) and the Centers for Medicare and Medicaid have invested more than $\$ 50$ billion dollars in the last 15 years to improve training, recruitment and retention (IOM, 2008). This is ongoing through the National Direct Service Workforce Resource Center, a spinoff of the Centers previously mentioned. In the U.S., direct care workers for older persons 
Integration or Specialization in Gerontology: Sweden and the United States?

and those with disabilities are estimated to be the largest occupational group next to retail salespersons in 2022 (PHI, 2014). These are just a few of the initiatives in process to improve and increase the number of appropriate staff to care for older persons.

In 2014, the International Federation of Social Workers (IFSW), called for promotion and expansion of gerontological, geriatric, and cultural competency education and training for all social workers and other health, mental health, and social service providers; recruitment and retention of gerontological and geriatric specialists; safe working environments, fair conditions, and just compensation for all workers in the field of aging; and promotion and strengthening of the social work role in meeting the biopsychosocial needs of older adults through practice, policy, research, and advocacy (IFSW, 2014).

It is essential that societies do not assume that all older people have the same or similar desires and needs (Ball, et al., 2009). We generally become more heterogeneous, not less, as we age and have different experiences and live in different social contexts, with varying resources available on which to call. Many of the issues we face in late life, for example appropriate housing, are, in part, a reflection of a lack of options that older people have - the choices available do not reflect the diversity in health and social care needs, socioeconomic backgrounds, and other characteristics of older people. If we are to address demographic changes, we need to recognize increasing, not decreasing, diversity in characteristics and inequalities with age. So the need for a larger and more broadly educated and prepared workforce in many fields (such as housing and public policy), is critical in both countries.

\section{Discussion}

As we have shown here, the United States offers vastly more degrees at all levels of postsecondary education specifically in gerontology, even if it is within a specific disciplinary focus, such as counseling, psychology, or social work. Increasing on-line certificate programs offer basic, yet focused, education about elders and elder care for working professionals. Sweden, on the other hand, builds its 
Integration or Specialization in Gerontology: Sweden and the United States?

gerontological workforce and researchers through disciplines such as social work, nursing, or oral health, and generally not through programs with a specific degree in gerontology, though Sweden has an abundance of research related to aging, much from an interdisciplinary approach. Thus, while Sweden produces a vast array of research on older people, there are only three academic Professors of Gerontology in the entire country. Sweden's system also focuses much more on on-the-job training for people working with seniors and starts people sooner in positions that, comparably, in the U.S. would require a specific degree in gerontology, whether at the bachelor or master level. There are multiple master's and $\mathrm{PhD}$ programs in gerontology in the United States and only one Master's degree in Sweden, and doctoral programs in general social science fields that allow one to focus on aging if one chooses.

What should gerontology education and training look like? Deschodt, de Casterlé, \& Milisen (2010) and Kydd, et al. (2014) suggest that the amount of gerontological care in the curriculum is important in order to promote and foster positive attitudes towards the old. They suggest that gerontological care should be integrated into different subjects, something Fagerberg \& Gilje (2007) strongly disagreed with in their study of nursing education in Sweden and the U.S., and they advocated for additional, aging-specific courses to be offered. Yet, all these authors conclude that education is important in order to raise the level of knowledge and understanding of the social and health care problems older people might have. Both countries have clearly taken some first steps on that path through clear and focused initiatives, as noted above. Such initiatives are key to building, training, and retaining qualified workers in our aging societies and we must sustain them, even in the face of competing interests.

Investment in education, prevention and basic care will reduce the investment in other forms of health. In the U.S., we have made steps in that direction with the Affordable Care Act, and a slightly larger program for home care, which is much less expensive than nursing home care. In Sweden, we can see that eligibility for home care services has become more and more stringent, leaving really just those who might need skilled nursing care, to have some home care for as long as they can. This is due to the 
Integration or Specialization in Gerontology: Sweden and the United States?

competing demands on public funds for social services, and the growing elderly population, who are living longer, as well as a shift to the notion that older people are better served by helping them maintain function and independence. So, Sweden also needs to be looking for ways to enhance preventive care. Through greater diffusion of aging education throughout many disciplines, a more coordinated effort towards prevention and longer years of healthy living could be accomplished. One of the ways to do this may be through greater emphasis on, and incentives for, applied research by the doctoral level programs in Sweden and the U.S. In both countries, much research remains basic or theoretical, and not necessarily tied to practice. Although Evidence-based Practice research has grown in both countries, there is also data that report that professionals do not have the time to read and implement that kind of research. We believe that a different approach to the relationship between research and practice could fill this gap.

We must understand that change will need to come from the individual, the private market sector, and civil society, as well as the government. The private sector is growing in all our lives and is increasingly delivering public services in both societies. Scharlach (2011), in comparing Sweden, Denmark and the United States, noted that while all three societies have core values of self-reliance and independence, how those show up in elder care are different. For example, in the U.S., traditionally, family and civil society have been the main care providers for older persons, while the government role has been a "safety net." In contrast, Sweden and Denmark have developed a welfare system where the government has taken primary responsibility for physical care. As the welfare state shrinks, however, Sweden has been looking to families and civil society to bolster care. Scharlach proposed that while Sweden's model is a "more humane” approach to aging, the U.S. has had extensive experience in how the voluntary and nonprofit sectors can support older persons, along with creative new approaches to provision of care. For example, in the U.S., many hospitals and non-profit organizations, such as the Family Caregiver Alliance (www. ) offer support groups and education for informal caregivers, which is relatively rare in Sweden. These kinds of initiatives could be a good investment for Sweden, as civil society's role increases. The U.S. could learn from Sweden's conscientious approach to a growing private 
Integration or Specialization in Gerontology: Sweden and the United States?

market, where quality control is important. As the role of government in both societies shifts, we believe that one important and appropriate task the governments can do is to provide incentives and opportunities for adequate education and training of staff working with older persons.

As previously mentioned the educational debate remains focused on whether gerontological training and knowledge should be integrated across all subjects related to health and social care (which we find as an option for students in Sweden, but not a normal approach in the U.S. in studies in disciplines of practice (social work, nursing, oral health, etc.), or should such training be accomplished through more specialized education, which we see more commonly in the United States. In Sweden, the National Board of Health and Welfare (2012) recently endorsed the path of adding more specific courses at the post-secondary level.

We think this is one major area in which Sweden and the U.S. can learn from each other and move toward a more blended approach. We believe that Sweden needs more specialized courses in aging, as well as encouragement and, perhaps, incentives, for students to choose to work with older persons. We also believe the U.S. could increase the degree to which aging knowledge is integrated into courses in different health and social service fields, thus complementing the specializations in gerontology that currently exist, and providing more information about aging to other disciplines. This is somewhat more available in the U.S. at this time, as university and graduate students usually have the option to take courses in other disciplines to expand their perspectives (e.g., taking an Anthropology course while in a Gerontology program), whereas Sweden is not so flexible. These approaches reflect again, the underlying cultural values of the two societies - Sweden is more homogenous and structured similarly for all, while the U.S. is more flexible and allows more individualized approaches to education at most levels.

We also support Payne's (2001) call for a critical discussion of whether there is a common knowledge base that could be agree upon about, in this case, aging. He emphasizes the process of constructing and reconstructing knowledge over time and changing contexts. Are there fundamental areas of information that all who work with older people should know - biological changes, intellectual 
Integration or Specialization in Gerontology: Sweden and the United States?

changes, personal changes, social changes, etc.? Is there common knowledge that all health and social welfare programs could include, knowing there will be local, regional and national variations in the specifics of how those changes play out for individuals, communities, and societies? This also responds to Wrede, et al.'s (2008) note that we lack educational models and a knowledge base for care workers. This kind of agreement could also help in the current world of migration and globalization, given that most industrialized countries now have populations that are more diverse. More intentional blending of approaches in the two countries would also expand the number of people, even with different disciplinary lenses on issues related to late life, which would be available to address the growing needs in both nations.

Moody (1976) described 4 stages that a society can take towards support of older persons. First is the Rejection stage, where older persons are marginalized and "put away” in some senses (e.g., nursing homes). The second stage is Social Service, where health and social professionals are the decision-makers when it comes to who gets what kind of care. This is common in both countries. The third stage, Participation, allows older people to be involved in decisions about their care. This aim is publicly advocated for in Sweden and is part of their law. Social workers are responsible for making sure that older clients receive all available options and information. In fact, they can be held legally liable for not doing so. Yet, in reality, many professionals limit the options they provide to an older person to the ones they feel are most appropriate (F. Gabrielsson-Järhult, personal communication, March, 2015). The final stage of Self-Actualization is where individuals can truly choose for themselves, ideally in a society where many options are available. In addition, as both countries strive to meet the needs of their growing older populations within growing constraints of resources, the gap between ideals and practice can seem great. We advocate for exploring in other countries different models, strategies, and tactics for aligning goals and practices more closely. As an increasingly global village, that kind of effort is growing more easily achievable. We have found here that, even with many similarities, Sweden and the United States 
Integration or Specialization in Gerontology: Sweden and the United States?

have much to learn from each other in terms of education and training of those who support our older people.

\section{References}

Andersson, K. (2004). Det gäller att hushålla med kommunens resurser. Biståndsbedömares syn på äldres sociala behov. [Municipal resources must be used economically - a case officer's view of the social needs of the elderly]. Socialvetenskaplig tidskrift, 3-4, 275-292.

Ahnlund, P. (2008). Omsorg som arbete: om utbildning, arbetsmiljö och relationer i äldre- och handikappomsorgen [Caring as Work: About Education, Working Enviroment and Relationships in Elderand Disability Care]. Diss. Umeå University.

An Aging Nation: The Older Population in the United States. (2014). Population Estimates and Projections. Retrieved from https://www.census.gov/prod/2014pubs/p25-1140.pdf.

Arias, E. (2014). United States Life Tables, 2010. National Vital Statistics, 63. Maryland: United States Department of Health and Human Services.

Astvik, W. \& Aronsson, G. (2000). Specialister eller generalister? Arbetsvillkor och omsorgskvalitet i hemtjänst- och boendestödsverksamhet. Stockholm: Arbetslivsinstitutet.

Axelsson, J. \& Elmståhl, S. (2002) Outbildad personal i hemtjänsten utsätter vårdtagarna för risk. I: Läkartidningen, nr 11:1178-1183.

Ball, M.M., Perkins, M.M., Hollingsworth, C., Whittington, F.J. \& King, S.V. (2009). Pathways to assisted living: The influence of race and class. Journal of Applied Gerontology, 28, 81-108. doi: 10.1177/0733464808323451. Published online before print October 1, 2008.

Barry, P. (2009). Silver surge: Who will take care of aging boomers? retrieved from http://www.aarp.org/relationships/caregiving/info-04-2009/silver_surge_who.html 
Integration or Specialization in Gerontology: Sweden and the United States?

Borell, K. \& Ghanafareeon Karlsson, S. (2003) Reconceptualising intimacy and aging. Living apart together. In S. Arber, K. Davidson \& J. Ginn (Eds.), Gender and Ageing: New Directions: 47-62. Buckingham, UK: Open University Press.

Centers for Disease Control. (2003). Trends in aging-United States and worldwide. (Public Health and Aging). Morbidity and Mortality Weekly Report. (Feb. 14). Retrieved from (http://www.cdc.gov/mmwr/preview/mmwrhtml/mm5206a2.htm)

Commission on the Future of Sweden. (2013). Future challenges for Sweden: Final report from the Commission on the Future of Sweden. Stockholm, SE: Prime Minister's Office.

Davey, A., Malmberg, B. \& Sundeström, G. (2014). Aging in Sweden: Local variation, local control. The Gerontologist, 54: 525-32. doi: 10.1093/geront/gnt124.

Deschodt, M., de Casterlé, BD, \& Milisen, K. (2010). Gerontological care in nursing education programmes. Journal of Advanced Nursing, 66, 139-48.

Engström, G. \& Fegerberg, I. (2011). Attitudes towards older people among Swedish health care students and health care professionals working in elder care. Nursing Reports, 1 (1). doi: http://dx.doi.org/10.4081/nursrep.2011.e2

Fagerberg, I. \& Gilje, F. (2007). A comparison of curricular approaches of care of the aged in Swedish and US nursing programs. Nurse Education in Practice, 7, 358-364.

Goulding, M.R., Rogers, M.E., \& Smith, S.M. (2003). Public health and aging: Trends in aging -United States and worldwide. Morbidity and Mortality Weekly Report, 52, 101-106.

Gutman, G. (2010). Universities Offering Post-Graduate Degrees in Gerontology. Vancouver, B.C.: Simon Fraser University.

IMS 2009-126-179. Personalutbildning i äldreomsorg-blir den till nytta för de äldre? En utvärdering av kompetensstegen. 
Integration or Specialization in Gerontology: Sweden and the United States?

International Federation of Social Workers (2014). Ageing and older adults. Retrieved from http://ifsw.org/policies/ageing-and-older-adults/.

Jönson, H. \& Nilsson, M. (2009). Äldre I massmedierna - osynliga eller förknippade med problem. In Jönson, H. (ed.). Åldrande, åldersordning, ålderism. Norrköping: Nationella institutet för forskning om äldre och åldrande, Institutionen för samhälls- och välfärdsstudier, Linköpings universitet.

Kemp, C. (2008). Negotiating transitions in later life: Married couples in assisting living. Journal of Applied Gerontology, 27, 231-251. Doi: 10.1177/073346480731156.

Kydd, A., Touhy, T., Newman, D., Fagerberg, I. \& Engström. G. (2014). Attitudes towards caring for older people in Scotland, Sweden and the United States. Nursing Older People, 26, 33-40.

Lachs, M. \& Pillemer, K. (2015). Elder abuse. New England Journal of Medicine, 373, 1947-56. doi:10.1056/NEJMra1404688.

Martinson, M. \& Berridge, B. (2014). Successful aging and its discontents: A systematic review of the social gerontology literature. The Gerontologist 0(0) (Special issue, Successful Aging), 1-12. doi: 10.1093/geront/gnu037. First published online: May 9, 2014

McLaughlin, S., Connell, C.M., Herringa, S.G., Li, L.W., \& Roberts, J.S. (2010). Successful aging in the United States: Prevalence estimates from a national sample of older adults. Journals of Gerontology, Series B: Psychological Sciences and Social Sciences, 65B, 216-226. Published online 2009 Dec 14. doi: 10.1093/geronb/gbp101.

Moody, H.R. (1976). Philosophical presuppositions of education for older adults. Educational Gerontology, I, 1-16.

National Institute of Aging, National Institutes of Health, \& Department of Health and Human Services (2007). Growing older in America: The Health and Retirement Study. Washington, D.C. 
Integration or Specialization in Gerontology: Sweden and the United States?

National Board of Health and Welfare (2012). Okad kompetens inom geriatric och gerontology: Forslag till utformning och geromforande av satsning. Artikelnummer 2012-2-5. ISBN 978-91-86885-977.

Parker, M. (2000). Sweden and the United States: Is the challenge of an aging society leading to a convergence of policy? Journal of Aging Social Policy, 12: 73-90.

Payne, M. (2001). Knowledge bases and knowledge biases in social work. Journal of Social Work, 2, 133-146.

Scharlach, A. (2011). Aging in Sweden and Demark. Center for the Advanced Study of Aging Services). University of California: Berkeley, California.

Schellevis, F.G. (2013). Editorial on Epidemiology of multiple chronic conditions: An international perspective. Journal of Comorbidity, 3, 36-40.

SOU. (2007). Att lära nära. Stöd till kommuner för verksamhetsnära kompetensutveckling inom omsorg och vård av äldre. Stockholm: Socialdepartementet.

SOU. (2008). Värdigt liv I äldreomsorgen. Betänkande av välfärdsutredingen. Stockholm: Socialdepartementet.

Spencer, S., Martin, S., Bourgeault, I.L. \& O’Shea, E. (2010). The Role of Migrant Care Workers in Ageing Societies: Report on Research Findings in the United Kingdom, Ireland, Canada and the United States. Geneva, SZ: International Organisation for Migration.

Statistics Sweden. (2015). Stockholm, Sweden: Forecast Institute.

Statistics Sweden. (2008). Demographic Reports. The future population of Sweden 2006-2050.

SOU 2007:88. Att lära nära. Stöd till kommuner för verksamhetsnära kompetensutveckling inom omsorg och vård av äldre. Stockholm: Socialdepartementet 
Integration or Specialization in Gerontology: Sweden and the United States?

Thorslund, M. (2002) Dagens och morgondagens vård och omsorg. I Andersson, L. (red.) Socialgerontologi. Lund: Studentlitteratur.

Trydegård, G-B. \& Thorslund, M. (2010). One Uniform Welfare State or a Multitude of Welfare Municipalities? The evolution of Local Variation in Swedish Elder Care. Social Policy and Administration. 44, 495-511.

Tymowski, J. (2014). European Year for Active Ageing and Solidarity Between Generations (2012). European Implementation Assessment. Brussels: European Parliamentary Research Service.

Törnquist, A. (2006). Vård- och omsorgsassistentens kompetens - en litteraturgenomgång. S Stockhom: Socialstyrelsen.

Walker, A. (2002). A strategy for active ageing. International Social Security Review. Vol. 55. (1) 121139.

Wilinska, M. (2012). Spaces of (non)ageing: A discoursive study of inequalities we live by. Jönköping University: Diss.

Wrede, S., Henriksson, L., Host, H., Johansson, S. \& Dybbroe. B. (2008). Care Work in Crisis. Reclaiming the Nordic Ethos of Care. Lund: Studentlitteratur.

Yee, Y-S., Shin, S-H. \& Greiner, P.A. (2015). Can education change attitudes towards aging? A quasiexperimental design with a comparison group. Journal of Nursing Education and Practice, 5: 9099. 